\title{
Disruption of biological rhythms as a core problem and therapeutic target in mood disorders: the emerging concept of "Rhythm-regulators"
}

\author{
Konstantinos N Fountoulakis
}

From $1^{\text {st }}$ International Congress on Neurobiology and Clinical Psychopharmacology and European Psychiatric Association Conference on Treatment Guidance

Thessaloniki, Greece. 19-22 November 2009

\section{Background}

Biological rhythms was always considered to be disrupted in depression with the predominant theory being that of hyperarousal. However, recent data suggest that it might be more appropriate to suggest that depressed patients are incapable of achieving and maintaining that particular level of internal homeostasis which permits the organism to function smoothly, to lower enough the level of arousal during sleep, so that quality of sleep is good, and to increase this level enough during the day so as the person can function properly. Therefore the transition from one state to another is somewhat problematic, delayed, incomplete and de-synchronized. Thus agents with a 'rhythm stabilizing' effect could be beneficial in the treatment of mood disorders. Such an agent should have a beneficial effect on restoring and stabilizing the rhythm of a physiological function and not pushing it towards a specific pole, or inducing the opposite pole; it should also allow response to both internal and environmental stimuli and zeitgebers and restore synchronization of the various body rhythms and not inducing or worsening dysynchonization. Agomelatine could represent the first of a new class that is

3rd Department of Psychiatry, Aristotle University of Thessaloniki, Greece 'rhythm stabilizing antidepressant' but further research is necessary to support this.

Published: 22 April 2010

doi:10.1186/1744-859X-9-S1-S226

Cite this article as: Fountoulakis: Disruption of biological rhythms as a core problem and therapeutic target in mood disorders: the emerging concept of "Rhythm-regulators". Annals of General Psychiatry 2010 9(Suppl 1):S226.
Submit your next manuscript to BioMed Central and take full advantage of:

- Convenient online submission

- Thorough peer review

- No space constraints or color figure charges

- Immediate publication on acceptance

- Inclusion in PubMed, CAS, Scopus and Google Scholar

- Research which is freely available for redistribution

Submit your manuscript at www.biomedcentral.com/submit
C Biomed Central 